\title{
APPLICATION OF INSIDE OUTSIDE CIRCLE (IOC) MODEL TO IMPROVE SPEAKING SKILLS AND COOPERATION TO THE THEME OF ENERGY AND CHANGES FOR THIRD GRADE STUDENTS OF SD NEGERI 1 KUTOSARI
}

\author{
Indri Novianti ${ }^{1}$, Kartika Chyrsti Suryandari², Rokhmaniyah ${ }^{3}$ \\ Universitas Sebelas Maret \\ e-mail: indrinovianti@student.uns.ac.id
}

\section{Article History}

accepted 01/06/2020

Abstract: The study aimed to apply the steps of inside outside circle (ioc) model and to improve student speaking skills and cooperation. The research was a collaborative Classroom Action Research (CAR) carried out in three cycles. The subjects were third grade students of SD Negeri 1 Kutosari in academic year of 2019/2020. Qualitative data was the application of Inside Outside Circle (IOC) model. Quantitative data was the increasing student speaking skills and cooperation. The results showed that Inside Outside Circle (IOC) model improved student speaking skills and cooperation in five steps. It was proven by oral exam percentages which were $70.32 \%$ in the first cycle, $79.83 \%$ in the second cycle, and $89.01 \%$ in the third cycle. The student cooperation percentages were $60.83 \%$ in the first cycle, $75.57 \%$ in the second cycle, and $84.25 \%$ in the third cycle. It concludes that there is significant improvement of student speaking skills by the application of Inside Outside Circle (IOC) model.

Keywords: inside outside circle (ioc), speaking skills, cooperation

\begin{abstract}
Abstrak: Penelitian ini bertujuan untuk menerapkan langkah model Inside Outside Circle (IOC), meningkatkan keterampilan berbicara dan kerja sama siswa. Penelitian ini merupakan penelitian tindakan kelas (PTK) kolaboratif yang dilaksanakan dalam tiga siklus. Subjek penelitian ini adalah siswa kelas III SD Negeri 1 Kutosari tahun ajaran 2019/ 2020. Data yang digunakan berupa data kualitatif yaitu penggunaan model Inside Outside Circle dan data kuantitatif yaitu peningkatan keterampilan berbicara dan kerja sama siswa. Hasil penelitian menunjukkan bahwa model Inside Outside Circle yang dilaksanakan dengan lima langkah dapat meningkatkan keterampilan berbicara dan kerja sama siswa dibuktikan dengan hasil persentase tes lisan pada siklus I sebesar $70.32 \%$, siklus II menjadi $79.83 \%$, dan siklus III meningkat menjadi $89,01 \%$. Persentase peningkatan kerja sama siswa setiap siklus yaitu siklus I sebesar $60,83 \%$, siklus II sebesar 75,57\%, dan siklus III sebesar $84,25 \%$. Berdasarkan hasil analisis yang dilakukan berarti terdapat peningkatan yang signifikan terhadap keterampilan berbicara siswa yang dibelajarkan dengan model Inside Outside Circle, maka dapat direkomendasikan bahwa model pembelajaran Inside Outside Circle dapat digunakan sebagai alternatif model pembelajaran di Sekolah Dasar.
\end{abstract}

Kata kunci: Inside Outside Circle (IOC), keterampilan berbicara, dan kerja sama. 


\section{PENDAHULUAN}

Bahasa sebagai alat komunikasi memiliki peran penting bagi siswa baik dalam proses pendidikan maupun kehidupan bermasyarakat. Salah satu aspek keterampilan berbahasa yang penting adalah keterampilan berbicara. Keterampilan berbicara membantu siswa untuk mengekspresikan pikiran dan perasaannya sesuai dengan situasi pada saat dia sedang berbicara. Pembelajaran keterampilan berbicara penting dikuasai siswa agar mampu mengembangkan kemampuan berpikir, membaca, menulis, dan menyimak ujar Farris (Kariani, 2016).

Keterampilan berbahasa lisan memudahkan siswa untuk berkomunikasi dengan orang lain. Selain itu, keterampilan berbicara juga memudahkan siswa membangun relasi dengan orang-orang di sekelilingnya baik dengan guru maupun teman sebaya. Adanya komunikasi dengan teman membuat mereka bisa saling bekerja sama selama kegiatan pembelajaran berlangsung. Kerja sama sangat penting bagi perkembangan sosial siswa. Rukiyat (Yulianti; Djatmika; \& Santoso, 2016) mengatakan karakter kerja sama penting dimiliki oleh setiap siswa pada jenjang pendidikan Sekolah Dasar (SD), karena dapat melatih siswa dalam memahami, merasakan, dan melaksanakan aktivitas kerja sama guna mencapai tujuan bersama.

Berdasarkan observasi awal, diketahui bahwa pembelajaran yang dilaksanakan belum memberi kesempatan yang luas bagi siswa untuk bebas mengekspresikan ide dan gagasannya. Siswa masih malu untuk bertanya ketika diberi kesempatan bertanya oleh guru, pembelajaran yang dilakukan masih berpusat pada guru, dan siswa masih senang melakukan kegiatan secara individual. Kondisi tersebut berdampak pada ketuntasan hasil belajar Bahasa Indonesia aspek berbicara pada Penilaian Tengah Semester (PTS) semester ganjil mata pelajaran bahasa Indonesia indikator menyampaikan gagasan pada siswa kelas III yang berjumlah 26 orang siswa masih tergolong rendah, dengan nilai rerata siswa hanya mencapai 63,70, sedangkan nilai yang diharapkan sesuai dengan Kriteria Ketuntasan Minimal (KKM) adalah 73. Dari 26 orang siswa, hanya 7 siswa saja yang memperoleh nilai di atas KKM dengan persentase $24 \%$, sedangkan 19 siswa lainnya belum dapat memenuhi KKM atau masih berada di bawah KKM dengan persentase $76 \%$.

Dari uraian permasalahan tersebut, maka pembelajaran yang dilakukan perlu diadakan perbaikan. Pembelajaran akan lebih bermakna jika ditunjang dengan suatu kegiatan yang menyenangkan dan praktek langsung. Seperti yang dikatakan oleh Najib (2016) belajar akan lebih bermakna jika anak mengalami langsung apa yang dipelajarinya dengan mengaktifkan lebih banyak indera daripada hanya mendengarkan orang atau guru menjelaskan. Salah satu model yang ditunjang dengan kegiatan yang menyenangkan dan praktek langsung adalah model pembelajaran Inside Outside Circle (IOC). Model Inside Outside Circle (IOC) membantu siswa untuk bisa menyampaikan informasi secara lisan kepada temannya. Selain itu, model IOC ini juga menuntut kerja sama siswa dalam kelompok agar dapat bertukar informasi. Seperti yang dikemukakan oleh Rahmania (2017) bahwa "Inside/Outside Circles are particularly useful for: differentiation, kinesthetic learners, conversation practice, and community-building in the classroom" yang artinya model Inside Outside Circle (IOC) sangat berguna untuk pemerataan tugas sehingga memberikan tanggung jawab kepada masing-masing siswa untuk berperan aktif selama pembelajaran, siswa saling bekerja sama untuk mendapat hasil yang masksimal sehingga terciptalah pembelajaran yang efektif.

Model Inside Outside Circle diperkenalkan pertama kali oleh Spencer Kagan pada tahun 1990 merupakan model pembelajaran kooperatif dengan sistem lingkaran kecil dan lingkaran besar yang terdiri dari kelompok lingkaran dalam dan kelompok lingkaran luar yang memberikan kesempatan pada siswa agar saling berbagi informasi pada saat yang bersamaan (Modifikasi Andhika dkk; Kurniasih dkk; \& Shoimin). Model 
pembelajaran Inside Outside Circle menurut Shoimin (Jauhar; Kadir; \& Wahyuni, 2017) memiliki 10 tahapan-tahapan pembelajaran pada umumnya, yaitu: 1) guru membagi satu kelompok beranggotakan 3-4 orang; 2) tiap kelompok mendapatkan tugas mencari informasi berdasarkan pembagian tugas; 3) setiap kelompok mengerjakan tugas secara mandiri; 4) seluruh siswa berkumpul tidak berdasarkan kelompok; 5) separuh kelas berdiri membentuk lingkaran kecil dan menghadap keluar; 6) separuh kelas lainnya membentuk lingkaran di luar lingkaran pertama menghadap ke dalam; 7) dua siswa yang berpasangan dari lingkaran kecil dan besar berbagi informasi; 8) kemudian siswa berada di lingkaran kecil diam di tempat, sementara siswa yang berada di lingkaran besar begeser satu atau dua langkah searah jarum jam; 9) selanjutnya siswa berada di lingkaran besar yang membagi informasi; dan 10) pergerakan dihentikan jika anggota kelompok lingkaran dalam dan luar sebagai pasangan asal bertemu kembali. Namun, peneliti merangkum langkah model Inside Outside Circle menjadi 5 langkah, yaitu menetapkan siswa di lingkaran dalam, menetapkan siswa di lingkaran luar, menyampaikan tugas siswa di lingkaran dalam, menginstruksi siswa untuk bertukar posisi, dan menyampaikan tugas siswa di lingkaran luar.

Berdasarkan uraian di atas, peneliti melakukan penelitian dengan tujuan (1) mendeskripsikan langkah penerapan model Inside Outside Circle (IOC) pada Tema Energi dan Perubahannya. (2) meningkatkan keterampilan berbicara siswa melalui penerapan model Inside Outside Circle (IOC). (3) meningkatkan kerja sama siswa melalui penerapan model Inside Outside Circle (IOC).

\section{METODE}

Penelitian yang dilakukan adalah penelitian tindakan kelas kolaboratif yang dilaksanakan dalam tiga siklus. Penelitian ini melibatkan peneliti dan guru kelas III SDN 1 Kutosari. Subjek dalam penelitian yaitu guru dan siswa kelas III yang berjumlah 26 siswa dengan karakter siswa antara lain: 1) siswa masih kurang jelas dalam menyampaikan pendapat baik dari segi volume maupun pengucapan; 2) tanggapan/ pendapat yang disampaikan siswa tidak sesuai dengan materi yang diajarkan; 3) siswa masih senang menyendiri saat kegiatan kelompok; 4) siswa kurang serius dalam proses diskusi (memberi tanggapan). Data pada penelitian ini meliputi data kualitatif berupa penerapan model Inside Outside Circle (IOC) dalam pembelajaran dan data kuantitatif berupa peningkatan keterampilan berbicara dan kerja sama. Data pada penelitian ini bersumber dari guru dan siswa kelas III dengan teknik pengumpulan data menggunakan tes, observasi, wawancara, dan angket. Uji validitas data menggunakan triangulasi teknik dan triangulasi sumber. Analisis data penelitian meliputi kegiatan reduksi data, penyajian data, dan penarikan kesimpulan. Indikator kinerja pada penelitian ini yaitu pelaksanaan langkah pembelajaran dengan model Inside Outside Circle (IOC), peningkatan keterampilan berbicara dan kerja sama dan respon siswa terhadap pembelajaran melalui penerapan model IOC. Dengan memperhatikan kondisi dan kemampuan subjek penelitian yang cukup baik maka peneliti menentukan target ketercapaian $80 \%$. Prosedur dalam penelitian ini meliputi tahap perencanaan, pelaksanaan, pengamatan, dan refleksi.

\section{HASIL DAN PEMBAHASAN}

Penggunaan model Inside Outside Circle pada tema energi dan perubahannya meliputi langkah-langkah: (1) menetapkan siswa di lingkaran dalam, (2) menetapkan siswa di lingkaran luar, (3) menyampaikan tugas siswa di lingkaran dalam, (4) menginstruksi siswa bertukar posisi, (5) dan menyampaikan tugas siswa di lingkaran luar. Langkah-langkah model yang digunakan peneliti dalam pembelajaran mengacu pada langkah-langkah yang dikemukakan oleh Huda (2013) yang disimpulkan menjadi langkah yang telah disebutkan di atas. Pembelajaran dengan penggunaan model 
Inside Outside Circle diamati oleh observer berdasarkan lembar observasi terhadap guru dan siswa. Hasil observasi pada siklus I, siklus II, dan siklus III ditampilkan pada Tabel 1.

Tabel 1. 1 Rerata Hasil Observasi Penggunaan Model Inside Outside Circle

\begin{tabular}{|c|c|c|c|c|}
\hline \multirow{2}{*}{\multicolumn{2}{|c|}{ Sumber Data }} & \multicolumn{3}{|c|}{ Siklus } \\
\hline & & I & II & III \\
\hline Guru & Rerata & 2,29 & 3,44 & 3,89 \\
\hline Siswa & Rerata & 2,19 & 3,24 & 3,74 \\
\hline
\end{tabular}

Berdasarkan tabel 1 dapat diperoleh informasi bahwa proses pembelajaran pada siklus I, siklus II dan siklus III mengalami kenaikan. Rerata hasil observasi terhadap capaian guru pada siklus I yaitu 2,29, pada siklus II yaitu 3,44 , dan pada siklus III yaitu 3,89. Rerata hasil observasi terhadap capaian siswa pada siklus I yaitu 2,19 , siklus II yaitu 3,24 , dan siklus III yaitu 3,74 . Data peningkatan keterampilan berbicara didapatkan dari hasil observasi tes lisan dan hasil evaluasi tes lisan saat kegiatan pembelajaran pada siklus I, siklus II, dan siklus III. Hasil peningkatan keterampilan berbicara yang diperoleh siswa pada siklus I, siklus II, dan siklus III ditampilkan pada Tabel 2.

Tabel 2 Presentase Peningkatan Keterampilan Berbicara Siklus I, II, dan III

\begin{tabular}{llccc}
\hline \multirow{2}{*}{ Sumber Data } & & \multicolumn{3}{c}{ Siklus } \\
\cline { 3 - 5 } & & I & II & III \\
\hline Hasil Observasi & Persentase (\%) & 63,38 & 78,55 & 86,53 \\
\hline Hasil Tes & Rerata & 80,29 & 81,77 & 92,77 \\
\hline \multicolumn{2}{c}{ Total (\%) } & $\mathbf{7 0 , 3 2}$ & $\mathbf{7 9 , 8 3}$ & $\mathbf{8 9 , 0 1}$ \\
\hline
\end{tabular}

Berdasarkan tebel 2, dapat diperoleh informasi bahwa peningkatan keterampilan berbicara mengalami kenaikan yang signifikan. Persentase hasil pada siklus I sebesar 70,32 \%, siklus II sebesar 79,83 \%, dan siklus III sebesar 89,01\%. Peningkatan keterampilan berbicara pada siklus III telah mencapai indikator kinerja penelitian yang ditetapkan yaitu $80 \%$. Data peningkatan kerja sama didapatkan dari hasil observasi saat kegiatan pembelajaran pada siklus I, siklus II, dan siklus III. Hasil peningkatan kerja sama yang diperoleh siswa pada siklus I, siklus II, dan siklus III ditampilkan pada Tabel 3.

Tabel 3 Presentase Peningkatan Kerja Sama Siklus I, II, dan III

\begin{tabular}{llccc}
\hline \multirow{2}{*}{ No. } & \multirow{3}{*}{ Aspek } & \multicolumn{3}{c}{ Siklus } \\
\cline { 3 - 5 } & & $\mathrm{I}$ & $\mathrm{II}$ & $\mathrm{III}$ \\
\cline { 3 - 5 } & & $(\%)$ & $(\%)$ & $(\%)$ \\
\hline 1. & Komunikasi Antaranggota & 55.15 & 70.66 & 82.69 \\
\hline 2. & Saling Ketergantungan & 61.52 & 73.79 & 83.17 \\
\hline 3. & Tanggung Jawab & 58.64 & 76.19 & 86.05 \\
\hline 4. & Saling Menghargai & 68.02 & 77.64 & 85.09 \\
\hline Rerata & $\mathbf{6 0 . 8 4}$ & $\mathbf{7 4 . 5 7}$ & $\mathbf{8 4 . 2 5}$ \\
\hline
\end{tabular}

Berdasarkan tebel 3, dapat diambil informasi bahwa peningkatan kerja sama mengalami kenaikan. Persentase hasil pada siklus I sebesar 60,84\%, siklus II sebesar 
$74,57 \%$, dan siklus III sebesar $84,25 \%$. Peningkatan kerja sama pada siklus III telah mencapai indikator kinerja penelitian yang ditetapkan yaitu $80 \%$.

Penggunaan model Inside Outside Circle (IOC) pada tema energi dan perubahannya dapat meningkatkan keterampilan berbicara dan kerja sama siswa di kelas III SD Negeri 1 Kutosari. Hal ini sesuai dengan hasil penelitian yang dilakukan oleh Kurniawati, Arini \& Suarjana (2016) yang membuktikan bahwa model Inside Outside Circle (IOC) dapat meningkatkan keterampilan berbicara Bahasa Indonesia Kelas $\mathrm{V}$ secara signifikan. Pada penelitian ini penulis menekankan aspek keterampilan berbicara pada tema energi dan perubahannya berbeda dengan penelitian yang dilakukan oleh Kurniawati, Arini \& Suarjana (2016) yang lebih memfokuskan pada mata pelajaran Bahasa Indonesia saja. Pada hasil Penilaian Tengah Semester (PTS) semester ganjil tahun ajaran 2019/2020 terdapat 19 dari 25 siswa yang belum mencapai KKM dengan persentase ketuntasan hasil belajar hanya 24\%. Setelah dilakukan tindakan, persentase ketuntasan hasil belajar pada siklus I meningkat menjadi $70.32 \%$. Pada siklus II terjadi peningkatan kembali menjadi $79.83 \%$. Pada siklus III terjadi peningkatan kembali menjadi 89,01\%. Berdasarkan hasil di atas, dapat diketahui bahwa pada siklus I belum mencapai indikator kinerja penelitian yang ditetapkan.. Pada siklus II sudah mengalami peningkatan namun belum mencapai indikator kinerja penelitian yang ditetapkan. Kemudian pada siklus III kembali mengalami peningkatan dan mencapai indikator kinerja penelitian yang ditetapkan sebesar 89,01\%. Berdasarkan pembahasan hasil tentang hasil belajar siswa yang didukung penelitian yang telah dilakukan, dapat diambil kesimpulan bahwa penggunaan model Inside Outside Circle (IOC) dapat meningkatkan keterampilan berbicara dan kerja sama siswa di kelas III SD Negeri 1 Kutosari tahun ajaran 2019/2020.

Berdasarkan hasil angket yang disebar kepada siswa mengenai penerapan model Inside Outside Circle diperoleh informasi bahwa (a) semua siswa senang mengikuti pembelajaran; (b) semua siswa menyampaikan pendapat dengan lancar; (c) semua siswa bisa menjawab pertanyaan dari guru; (d) semua siswa berbicara dengan jelas, tidak telalu cepat, dan pandangan mata yang fokus; (e) semua siswa yang berbicara dengan sopan, menghormati teman, dan dengan rasa persaudaraan; ( $f$ ) semua siswa menjaga komunikasi antaranggota dalam kegiatan kerja sama; $(g)$ semua siswa menghormati teman dalam kelompok dan tidak memaksakan pendapat sendiri; (h) semua siswa menyelesaikan tugas secara mandiri; (i) siswa yang bertanggung jawab terhadap tugas individu dan tugas kelompok ada 96,16\%; (j) ada 92,30 \% siswa yang mendapatkan pengalaman baru dalam pembelajaran. Sesuai dengan penelitian yang dilakukan Andhika, Suardika, Wiyasa (2013) model IOC menuntut siswa untuk bekerja kelompok sehingga dapat memperkuat hubungan antar individu, memerlukan keterampilan berkomunikasi dan proses kelompok yang baik, unggul pada aktivitas siswa dalam menggali informasi, meningkatkan partisipasi siswa, serta memberikan kesempatan pada siswa untuk berinteraksi dan belajar bersama-sama sehingga membuat proses pembelajaran menjadi menarikdan tidak membosankan.

Berdasarkan hasil observasi langkah model Inside Outside Circle, ditemukan beberapa kendala dalam pembelajaran yaitu (a) guru kurang tegas dalam mengondisikan siswa untuk mengikuti pembelajaran; (b) ruang kelas yang tidak cukup luas; (c) siswa memilih-milih teman dalam diskusi antarkelompok; (d) siswa bergurau dengan teman saat guru memberikan pengarahan; (e) membutuhkan waktu yang cukup lama; (f) kondisi kelas kurang kondusif pada saat tes lisan. Kendala yang ditemukan sesuai dengan pendapat Andhika, Suardika, dan Wiyasa (2019) mengenai kekurangan dari pada penerapan model pembelajaran kooperatif tipe Inside Outside Circle adalah membutuhkan ruang kelas yang besar dan cukup lama sehingga disalah gunakan untuk bergurau. 
Berdasarkan kendala yang ditemui saat pembelajaran, solusi yang telah diterapkan guru yaitu: (a) peneliti memberikan koreksi kepada guru bahwa untuk lebih tegas lagi dalam mengondisikan siswa agar semua siswa siap mengikuti pembelajaran; (b) guru mengondisikan ruang kelas dengan merapikan meja dan bangku; (c) siswa dimotivasi untuk tidak membeda-bedakan teman; (d) siswa diajak melakukan ice breaking agar tertarik untuk mengikuti pelajaran; (e) guru memberi batasan waktu pada setiap langkah untuk menyingkat waktu; (f) siswa dimotivasi untuk tetap tenang dan fokus pada saat penilaian tes lisan, siswa di arahkan untuk mengingat kembali materi yang sudah dipelajari. Seperti yang disampaikan oleh Najati (2015), motivasi yaitu kekuatan penggerak yang membangkitkan aktivitas pada seseorang dan menimbulkan tingkah laku serta mengarahkan pada tujuan-tujuan tertentu. Jika dihubungkan dengan solusi memotivasi siswa untuk tetap tenang pada saat penilaian tes lisan siswa diarahkan untuk mengingat kembali materi yang sudah dipelajari. Berarti kekuatan penggerak dalam solusi ini yaitu siswa diarahkan untuk mengingat kembali materi yang sudah dipelajari agar pelaksanaan tes lisan berjalan dengan tertib dan tenang.

\section{SIMPULAN}

Berdasarkan hasil penelitian dapat disimpulkan bahwa penggunaan Inside Outside Circle dengan langkah-langkah, menetapkan siswa di lingkaran dalam, menetapkan siswa di lingkaran luar, menyampaikan tugas siswa di lingkaran dalam, menginstruksi siswa bertukar posisi, dan menyampaikan tugas siswa di lingkaran luar dapat meningkatkan keterampilan berbicara dan kerja sama pada tema energi dan perubahannya di kelas III SDN 1 Kutosari tahun ajaran 2019/2020 yang dibuktikan dengan persentase ketuntasan hasil belajar pada siklus I sebesar $70,32 \%$ menjadi $79,83 \%$ pada siklus II, dan menjadi $89,01 \%$ pada siklus III. Kendala yang ditemui yaitu: (1) guru kurang tegas dalam mengondisikan siswa; (2) ruang kelas yang tidak cukup luas; (3) siswa memilih-milih teman dalam diskusi kelompok; (4) siswa bergurau saat pembelajaran; (5) membutuhkan waktu yang cukup lama; (6) kondisi kelas kurang kondusif pada saat tes lisan. Adapun solusi yang diterapkan yaitu: (1) peneliti memberikan koreksi kepada guru bahwa untuk lebih tegas lagi dalam mengondisikan siswa; (2) guru mengondisikan ruang kelas dengan merapikan meja dan bangku; (3) siswa dimotivasi untuk tidak membeda-bedakan teman; (4) siswa diajak melakukan ice breaking agar tertarik untuk mengikuti pelajaran; (5) guru memberi batasan waktu untuk menyingkat waktu; (6) siswa di arahkan untuk mengingat kembali materi yang sudah dipelajari.

\section{DAFTAR PUSTAKA}

Andhika, I. Md. E., Suardika, I. Wyn. R., \& Wiyasa, I. Km. N. (2013). Pengaruh Model Pembelajaran Kooperatif Tipe Inside Outside Circle Berbasis Media Audio Visual Animation Terhadap Hasil Belajar IPS. Jurnal PGSD Undiksha, 4 (1)

Huda, M. (2013). Model-Model Pengajaran dan Pembelajaran. Yogyakarta: Pustaka Pelajar

Jauhar, ST., Kadir, A.,\& Wahyuni. (2017). Penerapan Model Pembelajaran Inside Outside Circle Dalam Meningkatkan Hasil Belajar IPS Siswa KelasIV SD Negeri 215 Kading Kecamatan Barebbo Kabupaten Bone. JIKAP PGSD: Jurnal IImiah IImu Kependidikan, 1 (1).

Kariani, V. (2016). Pada Siswa Peningkatan Keterampilan Berbicara Melalui Model Pembelajaran Kooperatif Tipe Artikulsi Kelas VI SD Inpres 3 Talise. e-Jurnal Bahasantodea, 4 (2) 
Kurniasih, I. \& Sani, B. (2016). Ragam Pengembangan Model Pembelajaran. Jakarta: Kata Pena

Kurniawati, C. I., Arini, N. W., \& Suarjana, M. (2016). Penerapan Model Pembelajaran Inside Outside Circle Untuk Meningkatkan Keterampilan Berbicara Bahasa Indonesia Kelas V. E-Journal PGSD Universitas Pendidikan Ganesha, 4 (1)

Najati, U. (2015). Hubungan yang Signiikan antara Attachment Orang Tua dengan Motivasi Belajar Anak Berkebutuhan Khusus di Sekolah Inklusif. Skripsi Tidak Dipublikasikan Universitas Islam Negeri Maulana Malik Ibrahim.

Najib, D.A. (2016). Pengaruh Penerapan Pembelajaran Bermakna (Meaningfull Learning) Pada Pembelajaran Tematik IPS Terpadu Terhadap Hasil Belajar Siswa Kelas III di MI Ahliyah IV Palembang. Jurnal IImiah PGMI (JIP), 2 (1)

Rahmania. (2017). The Effect of Inside-Outside Circle Strategy to Students' Vocabulary Mastery. Advances in Social Science, Education and Humanities Research, 104

Shoimin, A. (2014). Model Pembelajaran Inovatif dalam Kurikulum 2013. Yogyakarta: Ar- Ruzz Media

Yulianti, S. D., Djatmika, E. T., \& Santoso, A. (2016). Pendidikan Karakter Kerja Sama dalam Pembelajaran Siswa Sekolah Dasar Pada Kurikulum 2013. Jurnal Teori dan Praksis Pe,belajaran IPS, 1 (1) 